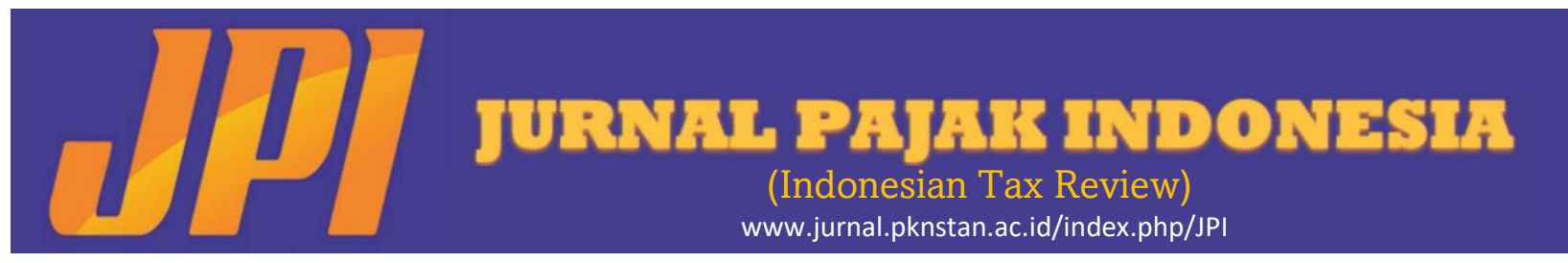

\title{
AGRESIVITAS PELAPORAN KEUANGAN DAN PENGHINDARAN PAJAK
}

\author{
Andyan Zakiy Pradhana \\ [Pegawai Direktorat Jenderal Pajak, Kementerian Keuangan RI] \\ Arif Nugrahanto \\ [Politeknik Keuangan Negara STAN] \\ Alamat Korespondensi: [arifn@pknstan.ac.id]
}

\section{INFORMASI ARTIKEL}

Diterima Pertama

[29092021]

Dinyatakan Diterima

[11112021]

KATA KUNCl:

pelaporan keuangan agresif, penghindaran pajak

KLASIFIKASI JEL:

Aggressive Reporting, Tax Compliance, Tax Evasion

\section{ABSTRAK}

Identification of tax avoidance is one of the substantial issues for tax authorities. Success in this stage ensure optimal tax compliance. To do that, financial statements become the object of critical analysis. This study seeks to identify the effect of financial statements (aggressive) on tax avoidance. The mineral and coal mining sector is chosen as the sample because it is one of the business sectors with a fairly high level of tax avoidance. There are 26 companies on the IDX that are the samples of this study. By regressing fixed effect panel data in the form of financial reports for 2012-2018, the results show that aggressive financial reporting has a positive effect on tax avoidance. With a confidence level of 99\%, every $1 \%$ increase in the level of aggressiveness of financial reporting equivalent to an increase in tax avoidance efforts of $4.6 \%$. For tax authorities, these findings can be used to assess the risk of non-compliance by taxpayers.

Identifikasi adanya upaya penghindaran pajak menjadi salah satu isu penting bagi otoritas pajak. Keberhasilan dalam proses ini dapat menjamin optimalnya fungsi pengawasan kepatuhan pajak yang dilakukan oleh otoritas pajak. Untuk melakukan itu, laporan keuangan menjadi objek analisis yang substansial. Penelitian ini berupaya mengidentifikasi pengaruh laporan keuangan (agresif) terhadap tindakan penghindaran pajak. Sektor pertambagan mineral dan batubara dipilih sebagai sampel karena merupakan salah satu sector usaha dengan tingkat penghindaran pajak yang cukup tinggi. Terdapat 26 perusahaan di BEl yang menjadi sampel penelitian ini. Dengan melakukan regresi fixed effect data panel berupa laporan keuangan tahun 2012-2018, hasil penelitian menunjukkan bahwa pelaporan keuangan yang agresif berpengaruh positif terhadap penghindaran pajak. Dengan tingkat keyakinan 99\%, setiap kenaikan tingkat agresivitas pelaporan keuangan sebesar $1 \%$, ekuivalen dengan adanya kenaikan upaya penghindaran pajak sebesar 4,6\%. Bagi otoritas pajak, temuan ini dapat digunakan untuk menilai risiko ketidakpatuhan wajib pajak dalam menjalankan fungsi pengawasan kepatuhan pemenuhan kewajiban pajak. 


\section{PENDAHULUAN}

\subsection{Latar Belakang}

Pemerintah Indonesia masih menghadapi masalah penerimaan perpajakan yang belum optimal. Tercatat bahwa rasio pajak terhadap Produk Domestik Bruto (PDB) sebesar 11,5\% di 2018. Bahkan bila kita hitung rasio pajak terhadap PDB dalam arti sempit (tanpa penerimaan PNBP sumber daya alam) angkanya hanya mencapai 10,3\% (www.cnbcindonesia.com).

Adanya praktik penghindaran pajak oleh para pelaku usaha dianggap menjadi salah satu penyebab rendahnya pencapaian penerimaan perpajakan Indonesia. Besley dan Persson (2014) mengutip Meltzer dan Richard menjelaskan bahwa salah satu faktor kunci yang menyebabkan rendahnya kinerja penerimaan pajak di negara berkembang adalah aktivitas penghindaran pajak.

Program pengampunan pajak pada tahun 2016 lalu pun dapat dimaknai dari dua sisi. Banyaknya jumlah Wajib Pajak yang ikut serta dalam tax amnesty dapat dianggap bahwa program tersebut berhasil. Namun, disisi lain hal tersebut menunjukkan masih tingginya fenomena penghindaran pajak di Indonesia. Lestari (2018) mengatakan bahwa ketidakpatuhan Wajib Pajak dapat dilakukan dengan cara tidak melaporkan sebagian atau seluruh kewajiban perpajakannya, dan kebijakan tax amnesty dimaksudkan untuk mengenakan kembali pajak yang belum dibayar dari kegiatan ekonomi bawah tanah ataupun pelaporan pajak yang tidak jujur. Dengan kata lain, dengan mengikuti amnesti pajak, secara tidak langsung Wajib Pajak mengakui kekeliruan dalam menghitung kemampuan finansialnya.

Di Indonesia, sektor yang diduga agresif dalam penghindaran pajak adalah sektor pertambangan mineral dan batubara (minerba). Wakil Ketua Komis Pemberantasan Korupsi (KPK) Laode M. Syarif menyebut kepatuhan Wajib Pajak pada sektor sumber daya alam atau sektor ekstraktif masih sangat rendah (www.okezone.com). Perilaku ketidakpatuhan sektor pertambangan di bidang perpajakan pertama kali disorot pada tahun 2010, ketika Gayus Tambunan tertangkap KPK atas kasus suap. PT Kaltim Prima Coal, PT Bumi Resources, dan PT Arutmin, tiga perusahaan yang berada di bawah kelompok bisnis Bakrie disebutsebut terlibat kasus dugaan manipulasi tunggakan pajak yang dilakukan dengan bantuan Gayus.

Di sisi lain, besarnya nilai ekonomi yang dihasilkan industri pertambangan mineral dan batubara ternyata tidak berbanding lurus dengan kontribusi pajaknya. Direktorat Jenderal Pajak (DJP) menyebutkan bahwa terdapat ketidaksamaan data perpajakan sektor pertambangan mineral dan batubara yang disediakan sejumlah lembaga, antara lain Kementerian Perdagangan, Kementerian Energi dan Sumber Daya Mineral hingga Direktorat Jenderal Bea Cukai (www.cnnindonesia.com). Lebih lanjut, ICW juga menyebutkan bahwa tren kontribusi penerimaan perpajakan sektor mineral dan batubara (minerba) terus menurun. Begitu pula tax ratio sektor pertambangan mineral dan batubara masih jauh di bawah tax ratio nasional, yaitu hanya mencapai angka 3,88\% di tahun
2016 (www.antikorupsi.org). Rendahnya tax ratio tersebut mengindikasikan adanya praktik penghindaran pajak oleh pelaku industri pertambangan.

Perusahaan terlibat dalam penghindaran pajak karena dipengaruhi oleh berbagai hal, salah satunya adalah adanya upaya pelaporan keuangan secara agresif. Dalam rangka memperbesar laba, salah satu cara yang dapat ditempuh adalah dengan menghemat beban, dan pajak merupakan salah satu komponen beban yang dapat dihemat (Dhaliwal, Gleason, \& Mills, 2004). Desai dan Dharmapala (2006) mengatakan bahwa manajer dapat berperilaku oportunistik dengan tujuan memperkecil laba fiskal. Manajer ingin meningkatkan laba komersial dan salah satu caranya adalah dengan memperkecil beban pajak dengan motivasi mendapat bonus. Oleh karena itu, upaya memperbesar laba yang dilakukan oleh perusahaan dapat berdampak pada besarnya beban pajak yang dilaporkan.

Berangkat dari latar belakang di atas, penulis termotivasi dalam penelitian ini untuk menguji hubungan antara suatu upaya manajemen laba, direpresentasikan melalui laporan keuangan (agresif), terhadap penghindaran pajak pada perusahaan pertambangan mineral dan batubara yang terdaftar di Bursa Efek Indonesia (BEI).

\section{KERANGKA TEORI DAN PENGEMBANGAN HIPOTESIS}

Agency theory Pertama kali dicetuskan oleh Jensen dan Meckling yang menyatakan bahwa hubungan keagenan timbul jika ada kontrak di mana satu pihak (prinsipal) membuat pihak lain (agen) untuk melakukan suatu perbuatan mewakili prinsipal. Dalam kontrak tersebut, prinsipal melimpahkan wewenang pengambilan keputusan kepada agen. Teori tersebut mendalilkan bahwa jika kedua belah pihak adalah ulitity maximizer (Godfrey, Hodgson, Tarca, Hamilton, \& Holmes, 2010). Hal ini sejalan dengan pendapat Watts dan Zimmerman (1978) yang mengasumsikan bahwa individu bertindak untuk memaksimalkan utilitas/kekayaan mereka sendiri dan akibatnya manajemen akan menerapkan standar akuntansi yang sesuai dengan kepentingannya sendiri. Dalam situasi tersebut, baik prinsipal maupun agen berusaha memenuhi keperluan mereka dan agen tidak selalu bertindak sesuai dengan keinginan prinsipal. Hal ini menimbulkan konflik kepentingan antara manajer dan pemegang saham. Oleh karena itu, menurut teori ini sistem kompensasi akan membantu menyelaraskan kepentingan manajer dengan kepentingan pemegang saham. Kompensasi ini didasarkan pada laba komersial, sehingga menurut teori ini angka akuntansi memainkan peran sentral dalam mengurangi konflik kepentingan antara manajer dan pemegang saham.

Senada dengan hal tersebut, Desai dan Dharmapala (2006) mengatakan bahwa kompensasi menciptakan motivasi bagi manajemen untuk meningkatkan after-tax firm value. Hal ini dapat mendorong manajer untuk melakukan pelaporan keuangan agresif dengan tujuan melaporkan laba yang 
baik. Besarnya nilai laba dipengaruhi oleh beban pajak, sehingga pelaporan keuangan agresif dapat melibatkan manipulasi laba fiskal yang nantinya mempengaruhi besarnya beban pajak yang dilaporkan.

Dilihat dari sudut pandang teori keagenan, sistem pemungutan pajak di Indonesia menggunakan sistem self assessment, dimana kedudukan pemerintah sebagai otoritas (prinsipal) perpajakan dan Wajib Pajak berperan sebagai agen pelaksana kewajiban perpajakan. Sistem self assessment akan menciptakan konflik kepentingan dimana pemungut pajak (fiskus) yang berharap adanya pemasukan sebesar-besarnya dari pemungutan pajak, sementara dari pembayar pajak (perusahaan) ingin memaksimalkan laba komersial.

Berdasarkan keterangan di atas, dapat disimpulkan bahwa menurut teori keagenan, Wajib Pajak memiliki insentif untuk memperkecil pembayaran pajaknya. Upaya memperkecil pembayaran pajak dengan cara yang dapat sepenuhnya legal disebut sebagai penghindaran pajak (Hanlon dan Heitzman, 2010).

\section{Penghindaran Pajak}

Dyreng, Hanlon, dan Maydew (2010) mengatakan bahwa penghindaran pajak secara luas mencakup segala sesuatu yang mengurangi beban pajak perusahaan relatif terhadap pendapatan komersial sebelum pajak. Brown (2012) mengatakan bahwa penghindaran pajak melibatkan pengaturan transaksi untuk mendapatkan keuntungan, manfaat, atau pengurangan pajak dengan cara yang tidak diinginkan oleh undang-undang perpajakan. Menurut Ardyaksa dan Kiswanto (2014) mengutip Mardiasmo mengatakan bahwa penghindaran pajak adalah usaha meringankan beban pajak dengan tidak melanggar undang-undang. Menurut OECD, Penghindaran pajak dapat diartikan sebagai pengaturan transaksi oleh Wajib Pajak yang dimaksudkan untuk mengurangi kewajiban pajaknya dan meskipun bisa sepenuhnya legal, namun biasanya bertentangan dengan maksud undang-undang.

Blaufus, Hundsdoerfer, Jacob, dan Sünwoldt (2016) mengatakan bahwa secara umum penghindaran pajak dan penggelapan pajak adalah metode alternatif untuk mengurangi pajak yang berbeda dalam hal keabsahannya dimana penghindaran adalah kegiatan yang dilakukan dalam batasan hukum (legal), sedangkan penggelapan pajak diluar batasan hukum (ilegal).

\section{Pelaporan Keuangan Agresif}

Healy dan Wahlen (1999) menjelaskan bahwa manajemen laba terjadi ketika manajer menggunakan pertimbangan dalam pelaporan keuangan dan dalam menyusun transaksi untuk mengubah laporan keuangan dengan tujuan mengelabui beberapa pemangku kepentingan tentang kinerja ekonomi perusahaan, atau untuk mempengaruhi kontrak yang bergantung pada angka akuntansi yang dilaporkan. Fischer dan Rosenzweig (1995) mengatakan bahwa manajemen laba adalah tindakan yang dilakukan manajer untuk meningkatkan (menurunkan) jumlah laba yang dilaporkan saat ini tanpa mempengaruhi peningkatan (penurunan) profitabilitas jangka panjang perusahaan. Ewert dan Wagenhofer (2005) mengatakan bahwa manajemen laba dapat terjadi karena manajemen memiliki kebebasan untuk memilih metode dan estimasi akuntansi yang akan digunakan.

Pelaporan keuangan agresif pada pembahasan ini merujuk pada manajemen laba dengan tujuan untuk memperbesar laba dengan cara yang dapat sesuai atau tidak sesuai dengan GAAP. Oleh sebab itu, dalam pembahasan ini pelaporan keuangan agresif memiliki konteks yang sama dengan manajemen laba yang bertujuan untuk memperbesar laba.

Scott (2015) menyebutkan bahwa salah satu teknik yang digunakan manajer untuk memperbesar laba yang dilaporkan dikenal dengan sebutan income maximization. Melalui teknik ini, perusahaan berusaha memperbesar laba yang diperoleh dengan maksud melaporkan kinerja yang baik. Manajer yang melakukan pola ini biasanya dimotivasi oleh keinginan mendapat bonus yang lebih tinggi. Selain itu perjanjian utang (debt covenant) juga memotivasi perusahaan untuk memaksimalkan laba. Maksimalisasi laba dilakukan untuk mendapatkan keuntungan yang lebih tinggi pada periode saat ini daripada seharusnya. Sementara itu, Phillips (1999) mengatakan bahwa pelaporan keuangan agresif dapat melibatkan pengakuan pendapatan lebih awal, kapitalisasi biaya secara berlebihan, serta memperpanjang periode penyusutan atau amortisasi.

Dalam kaitannya dengan penghindaran pajak, Frank et al. (2009) mengatakan bahwa dalam melakukan pelaporan keuangan agresif, perusahaan dapat memanfaatkan perbedaan perlakuan akuntansi yang ada pada peraturan perpajakan dan standar akuntansi sehingga perusahaan dapat meningkatkan laba komersial dan memperkecil laba fiskal di waktu yang sama. Hal ini meliputi teknik manajemen laba yang umum seperti mempercepat pengakuan pendapatan dan menunda pengakuan biaya dalam batas-batas GAAP untuk tujuan pelaporan keuangan, serta teknik yang lebih agresif seperti kapitalisasi biaya yang tidak tepat dan penyalahgunaan akun-akun allowance.

Sejalan dengan Frank et al. (2009), Kamila dan Martani (2014) mengatakan bahwa pelaporan keuangan agresif dapat melibatkan upaya manipulasi pendapatan kena pajak yang nantinya mempengaruhi besarnya beban pajak yang dilaporkan. Hanlon dan Heitzman (2010) mengatakan bahwa dalam upaya membesarbesarkan laba komersial, manajer dapat mengatur transaksinya sehingga menciptakan perbedaan laba komersial dan laba fiskal.

\section{Penelitian Sebelumnya}

Penelitian Frank, Lynch, dan Rego (2006) adalah penelitian pertama yang mencari hubungan antara pelaporan keuangan agresif dan penghindaran pajak. Mereka melakukan penelitian terhadap perusahaan yang ada di database Compustat dan bertujuan untuk menyelidiki apakah pelaporan keuangan agresif disertai dengan agresivitas 
perpajakan. Penelitian menggunakan regresi data panel dan cross sectional yang dilakukan untuk tahun 19912003. Mereka menggunakan beda tetap (PERMDIFF) sebagai proxy agresivitas perpajakan dan menggunakan akrual diskresioner (DACC) sebagai ukuran pelaporan keuangan agresif. Hasil analisis regresi data panel yang mereka lakukan menunjukkan bahwa pelaporan keuangan agresif berhubungan positif signifikan terhadap agresivitas perpajakan.

Lennox, Lisowsky, dan Pittman (2013) bertujuan untuk menguji apakah agresivitas perpajakan berhubungan dengan kecurangan akuntansi (accounting fraud) dalam periode 1981-2001. Mereka menggunakan regresi probit dengan asumsi bahwa variabel independen tidak bersifat eksogen atau memiliki pengaruh terhadap variabel dependen. Mereka juga menegaskan bahwa tidak seperti manajemen laba yang dapat sepenuhnya patuh pada GAAP, kecurangan akuntansi tentu saja melanggar GAAP karena merupakan manipulasi yang disengaja dari laporan keuangan untuk menciptakan informasi yang tidak sebenarnya tentang kesehatan keuangan perusahaan.

Berbeda dengan penelitian Frank et al. (2006), penelitian mereka tidak bertujuan untuk mencari pengaruh agresivitas pelaporan keuangan terhadap agresivitas perpajakan atau sebaliknya. Mereka melakukan analisis dengan membandingkan nilai kedelapan proxy penghindaran pajak bagi perusahaan yang melakukan accounting fraud dengan perusahaan yang tidak melakukan accounting fraud menggunakan regresi probit. Mereka menemukan bahwa perusahaan yang melakukan fraud memiliki ETR (BTD) yang lebih tinggi (rendah). Dengan kata lain, perusahaan yang melakukan manipulasi laba kurang agresif dalam segi perpajakannya.

Penelitian Amidu, Coffie, dan Acquah (2019) menyelidiki pengaruh transfer pricing dan manajemen laba terhadap penghindaran pajak. Studi ini mengambil sampel 40 perusahaan dari perusahaan multinasional non-finansial dan finansial Ghana. Penelitian ini pertama-tama menganalisis pengaruh antara transfer pricing dan penghindaran pajak, kemudian menganalisis pengaruh antara manajemen laba dan penghindaran pajak dan akhirnya menguji sensitivitas transfer pricing dan manajemen laba pada penghindaran pajak. Penelitian Amidu, Coffie, dan Acquah menggunakan selisih antara tarif pajak yang berlaku dengan effective tax rate (ETR) perusahaan sebagai proxy penghindaran pajak, dimana ETR dihitung sebagai beban pajak kini dibagi dengan laba bersih sebelum pajak perusahaan. Untuk mengukur tingkat manajemen laba perusahaan non-keuangan digunakan model Jones (1991) yang dimodifikasi oleh Dechow, Sloan, dan Sweeney (1995) dengan akrual diskresioner sebagai proxy (DACC). Sedangkan untuk mengukur tingkat manajemen laba perusahaan keuangan digunakan discretionary loan loss provision (DLLP).
Kamila dan Martani (2014) melakukan penelitian untuk mencari hubungan kausalitas antara pelaporan keuangan agresif dan perpajakan. Proxy yang digunakan untuk mengukur agresivitas perpajakan dalam penelitian ini adalah perbedaan permanen diskresioner (DPERM). Sedangkan proxy pelaporan keuangan agresif menggunakan model Jones yang dimodifikasi (DACC). Sampel yang digunakan dalam penelitian ini adalah perusahaan manufaktur yang terdaftar di BEI dan mencakup periode 4 tahun (20082011). Penelitian ini mengacu pada penelitian Frank et al. (2006) dan menggunakan model regresi data panel dalam analisisnya. Hasil penelitian Kamila dan Martani menemukan bahwa pelaporan keuangan agresif dan agresivitas perpajakan memiliki hubungan positif secara resiprokal.

Ridha dan Martani (2014) menguji pengaruh pelaporan keuangan agresif, kepemilikan keluarga, dan tata kelola perusahaan terhadap agresivitas perpajakan Perbedaan penelitian ini dengan penelitian Kamila dan Martani (2014) adalah pada variabel independennya ditambahkan kepemilikan keluarga dan tata kelola perusahaan. Selain itu sampel diperluas menjadi perusahaan manufaktur dan non-manufaktur yang terdaftar di BEI dalam periode 5 tahun (2008-2012). Hasil penelitian mereka menunjukkan bahwa pelaporan keuangan agresif berpengaruh positif signifikan terhadap agresivitas perpajakan dan sebaliknya.

Penelitian yang dilakukan oleh Hanna dan Haryanto (2015) dilakukan dengan merujuk pada Ridha dan Martani (2014), dengan perbedaan periode penelitian dari tahun 2010-2014 serta penggunaan proxy ETR untuk mengukur tingkat penghindaran pajak. Hasil penelitian mereka menunjukkan koefisien regresi pelaporan keuangan agresif terhadap agresivitas perpajakan menunjukkan arah positive sebesar 0,058 dengan $p$ value sebesar 0,088, atau berada diatas taraf signifikansi $(\alpha)=5 \%$. Kesimpulan yang diambil adalah pelaporan keuangan agresif tidak berpengaruh signifikan terhadap agresivitas perpajakan.

\section{METODE PENELITIAN}

Dalam penelitian ini model regresi linear berganda digunakan untuk melakukan analisis data panel. Populasi penelitian ini adalah perusahaan yang tergolong dalam kelompok perusahaan pertambangan mineral dan batubara yang terdaftar di Bursa Efek Indonesia (BEI). Berdasarkan data yang diperoleh peneliti per November 2019, populasi berjumlah 33 perusahaan. Untuk sampelnya, dipilih perusahaan yang memenuhi kriteria-kriteria tertentu, antara lain: perusahaan terdaftar di BEI sejak 2012, perusahaan tidak mengalami pergantian bidang usaha selain pertambangan batubara dan pertambangan mineral dan logam selama periode penelitian; perusahaan tersebut memiliki data lengkap, terkait variabel yang 
diteliti. Dari hasil pemilihan sampel tersebut, diperoleh 26 perusahaan.

Penelitian ini menghubungkan variabel dependen, yaitu penghindaran pajak yang diukur dengan proxy book-tax difference (BTD) dan variabel independen, yaitu pelaporan keuangan agresif yang diukur dengan proxy total akrual (TACC). Book-tax difference (BTD) digunakan sebagai proxy penghindaran pajak. Dalam pengukuran ini, tingkat penghindaran pajak dinilai dari besarnya BTD. Dengan kata lain, semakin besar nilai BTD maka tingkat penghindaran pajak perusahaan juga semakin tinggi.

Menurut Tang dan Firth (2011) Income-effect BTD banyak digunakan dalam studi di Amerika Serikat, di mana pertama-tama dilakukan gross up pada beban pajak pada tariff PPh Badan untuk memperoleh nilai estimasi laba fiskal, setelah itu dihitung selisih total laba komersial dan laba fiskal untuk menghasilkan BTD. Menurut Tang dan Firth (2011) penggunaan tax-effect BTD dapat mengeliminasi kelemahan estimasi yang ada pada income-effect BTD.

Untuk mengukur pelaporan keuangan agresif, penelitian ini mengacu pada beberapa penelitian sebelumnya yang menggunakan total akrual sebagai proxy, seperti Chen, (2010); Bergstresser dan Phillipon (2006); Dechow, Ge, dan Schrand, (2010); Gill, Biger, Mand, dan Mathur (2013). Menurut Dechow et al. (2010) besarnya nilai akrual mengindikasikan bahwa perusahaan memiliki kualitas laba yang buruk karena laba memiliki persistensi yang rendah. Menurut Bergstresser dan Phillipon (2006), manajemen laba melibatkan transfer pendapatan dari satu periode ke periode lain, dan total akrual adalah ukuran jumlah total transfer pendapatan tersebut. Menurut Richardson, Tuna, dan Wu (2002), nilai akrual yang dilaporkan dapat dianggap sebagai indikasi adanya kegiatan manajemen laba untuk memperbesar laba saat ini dan tidak berdampak jangka panjang. Selain itu, keunggulan pengukuran ini adalah memiliki keterkaitan langsung dengan sistem akuntansi berbasis akrual (Dechow et al., 2010).

Model penelitian yang digunakan mengadaptasi model yang digunakan Amidu et al. (2019) dengan beberapa penyesuaian, menjadi sebagai berikut:

BTD $=\alpha 0+\beta 1$ TACCit $+\beta 2$ LEVit $+\beta 3$ SIZEit $+\beta 4$ CAPINTit $+\beta 5$ LOSSit $+\beta 6$ AGEit $+\beta 7$ GPit $+\varepsilon$ it

BTDit : Book-tax difference. Laba sebelum Pajak Penghasilan konsolidasi*tariff PPh - (beban PPh kini Induk + Beban PPh kini anak) perusahaan $i$ pada tahun $t$

TACCit : Total accrual. Selisih antara laba bersih dengan arus kas bersih dari aktivitas operasi diskalakan dengan total aset periode sebelumnya perusahaan $i$ pada tahun $t$
LEVit : Leverage. Merupakan rasio utang jangka panjang terhadap total aset perusahaan $i$ pada tahun $t$

SIZEit : Ukuran perusahaan. Merupakan logaritma natural total aset perusahaan $i$ pada tahun $t$

CAPINTit : Capital intensif. Net aset tetap dibagi dengan total asset perusahaan $i$ pada tahun $t$

LOSSit : Rugi sebelum pajak penghasilan. Dummy variable, angka " 1 " apabila perusahaan rugi sebelum beban pajak dan "0" bila sebaliknya

GPit : Growth potential. Merupakan logaritma natural total aset perusahaan $i$ pada tahun $t$

AGEit : Usia perusahaan. Merupakan selisih antara tahun pendirian dan tahun laporan keuangan perusahaan $i$ pada tahun $t$

عit

: Error term

\section{HASIL PENELITIAN}

Berdasarkan tabel di bawah ini, diketahui bahwa rata-rata BTD adalah sebesar -0.00643 dengan standar deviasi berada pada 0.01143 . Nilai terendah sebesar -0.03095 sedangkan nilai tertinggi sebesar 0.01997. Selama periode pengamatan, nilai BTD dapat positif dan negatif. Nilai positif BTD menandakan bahwa laba komersial lebih besar dari laba fiskal. Sedangkan nilai negatif BTD menandakan bahwa laba komersial lebih rendah dari laba fiskal.

Tabel Statistik Deskriptif

\begin{tabular}{|l|c|r|r|r|r|}
\hline Variabel & Jumlah Observasi & \multicolumn{1}{c|}{ Mean } & Std. Dev & \multicolumn{1}{c|}{ Min } & \multicolumn{1}{c|}{ Max } \\
\hline BTD & 182 & -0.00643 & 0.01143 & -0.03095 & 0.01997 \\
\hline TACC & 182 & -0.04626 & 0.07617 & -0.18371 & 0.12970 \\
\hline LEV & 182 & 0.14945 & 0.15790 & 0 & 0.58378 \\
\hline LOSS & 182 & 0.31319 & 0.46507 & 0 & 1 \\
\hline GP & 182 & 0.07814 & 0.29364 & -0.34591 & 0.86627 \\
\hline AGE & 182 & 23.96154 & 12.50121 & 5 & 50 \\
\hline SIZE & 182 & 20.17533 & 1.28754 & 16.81622 & 22.71855 \\
\hline CAPINT & 182 & 0.39675 & 0.16197 & 0.05321 & 0.78778 \\
\hline BTD & $\begin{array}{l}\text { Laba sebelum pajak penghasilan konsolidasi*tariff PPh) }-(\text { beban PPh kini Induk + } \\
\text { Beban PPh kini anak) / total aset awal tahun }\end{array}$ \\
\hline TACCit & (Laba bersih - arus kas bersih dari operasi) / total aset awal tahun \\
\hline LEVit & Utang jangka panjang / total aset \\
\hline SIZEit & Logaritma natural total aset \\
\hline CAPINTit & Net aset tetap / total asset \\
\hline LOSSit & $\begin{array}{l}\text { Bernilaia 1 apabila perusahaan mengalami rugi sebelum beban pajak, dan 0 jika } \\
\text { sebaliknya }\end{array}$ \\
\hline GP & Perubahan pendapatan / pendapatan tahun sebelumnya \\
\hline AGE & $\begin{array}{l}\text { Selisih antara tahun di mana perusahaan memulai operasi dan tahun laporan } \\
\text { keuangan }\end{array}$ \\
\hline
\end{tabular}

Sumber: Penulis

Dilihat dari nilai mean, rata-rata perusahaan memiliki laba komersial di bawah laba fiskal. BTD (booktax difference) merupakan selisih antara laba sebelum pajak penghasilan konsolidasi dikalikan dengan tarif PPh dengan beban PPh kini induk dan anak, diskalakan dengan total aset. Beban pajak kini adalah nilai kewajiban perpajakan perusahaan yang dilaporkan dalam Surat Pemberitahuan Tahunan. Beban pajak kini mencerminkan penghasilan yang telah disesuaikan 
dengan perbedaan permanen, temporer dan semua penyesuaian lainnya yang merupakan hasil dari rekonsiliasi fiskal. Oleh karena itu, laba fiskal dapat lebih besar maupun lebih kecil dari laba sebelum pajak konsolidasi.

\section{Uji Asumsi Klasik}

Uji asumsi klasik yang dilakukan dalam penelitian ini meliputi uji Uji Normalitas normalitas, uji multikolinearitas, uji heteroskedastisitas, dan uji autokorelasi. Hasil pengujian normalitas dengan menggunakan uji Shapiro-Wilk menyatakan bahwa nilai Prob $>Z$ yang dihasilkan adalah sebesar 0.33337 . Hasil ini menunjukkan bahwa residual terdistribusi secara normal yang ditunjukkan oleh nilai probabilitas statistik Prob>z yang lebih besar dari tingkat signifikansi $\alpha 0,05$. Simpulan dari uji Shapiro-Wilk adalah model tidak mengalami masalah normalitas.

Dalam penelitian ini, pengujian multikolinearitas dilakukan dengan melihat nilai Variance Inflation Factor (VIF). Berdasarkan hasil pengujian, nilai VIF untuk semua variabel berada di bawah 10 kecuali untuk variabel SIZE yang memiliki nilai 13.23. Hasil ini menunjukkan bahwa variabel SIZE mengalami masalah multikolinearitas. Untuk mengatasi masalah ini, terhadap variabel SIZE dilakukan centering, yaitu mengurangi data variabel dengan masing-masing mean-nya.

Uji heteroskedastisitas dalam penelitian ini menggunakan modified wald test. Berdasarkan hasil pengujian terlihat bahwa model mengalami masalah heteroskedastisitas yang ditunjukkan oleh nilai probabilitas statistik chi-square sebesar 0.000 atau lebih kecil dari tingkat signifikansi $\alpha 0,05$. Dengan kata lain, $\mathrm{HO}$ ditolak dan model mengalami masalah heteroskedastisitas. Stata 15 memiliki opsi robust untuk mengatasi masalah heteroskedastisitas. Apabila heteroskedastisitas tidak disertai dengan autokorelasi, maka dapat diatasi dengan menambahkan opsi robust pada persamaan regresi, namun apabila kedua masalah tersebut muncul maka dapat diatasi dengan clustered standard error (Hoechle, 2007).

Dalam penelitian ini, untuk menguji ada tidaknya autokorelasi digunakan Wooldridge Test. Nilai Prob $>F$ yang dihasilkan sebesar 0,0346 , atau lebih kecil dari tingkat signifikansi 0,05. Berdasarkan hasil tersebut dapat disimpulkan bahwa model mengalami masalah autokorelasi. Untuk mengatasi kedua masalah ini, menurut Hoechle $(2007,286)$ dalam jurnal Stata, dapat ditambahkan opsi clustered standard error (fe cluster) dalam meregresi model penelitian.

\section{Uji Regresi Data Panel}

Berdasarkan uji Chow, uji LM dan uji Hausman yang telah dilakukan, bahwa model yang paling cocok digunakan dalam penelitian ini adalah regresi fixed effect (FE). Regresi ini dilakukan dengan tambahan opsi clustering. Hasil meregresikan variabel independen (TACC) dengan tujuh variabel independen lainnya sebagai kontrol terhadap variabel dependen (BTD), sebagai berikut.

Tabel Hasil Regresi

\begin{tabular}{|c|c|c|c|c|}
\hline \multicolumn{5}{|c|}{$\begin{aligned} \mathrm{BTD}= & \alpha_{0}+\beta_{1} \mathrm{TACC}_{\mathrm{it}}+\beta_{2} \mathrm{LEV}_{\mathrm{it}}+\beta_{3} \mathrm{SIZE}_{\mathrm{it}}+\beta_{4} \mathrm{CAPINT}_{\mathrm{it}}+\beta_{5} \mathrm{LOSS}_{\mathrm{it}}+\beta_{6} \mathrm{AGE}_{\mathrm{it}} \\
& +\beta_{7} \mathrm{GP}_{\mathrm{it}}+\varepsilon_{\mathrm{it}}\end{aligned}$} \\
\hline BTD & Coef. & Robust Std. Err. & $\mathrm{t}$ & $\mathrm{P}>|\mathrm{t}|$ \\
\hline TACC & 0.04611 & 0.01482 & 3.11 & 0.005 \\
\hline LEV & -0.01422 & 0.01090 & -1.3 & 0.204 \\
\hline SIZE & 0.00017 & 0.00418 & 0.04 & 0.967 \\
\hline CAPINT & 0.00274 & 0.00952 & 0.29 & 0.776 \\
\hline LOSS & -0.01343 & 0.00283 & -4.75 & 0 \\
\hline AGE & 0.00039 & 0.00044 & 0.91 & 0.373 \\
\hline GP & 0.00523 & 0.00266 & 1.97 & 0.06 \\
\hline Cons & -0.00893 & 0.01165 & -0.77 & 0.451 \\
\hline Prob $>F$ & 0 & & & \\
\hline $\mathrm{R}^{2}$ & 0.5150 & & & \\
\hline $\mathrm{R}^{2}$ adj. & 0.4954 & & & \\
\hline BTD $_{\text {it }}$ & \multicolumn{4}{|c|}{$\begin{array}{l}\text { (Laba sebelum pajak penghasilan konsolidasi*tariff PPh) - (beban } \\
\text { PPh kini Induk + Beban PPh kini anak) / total aset awal tahun }\end{array}$} \\
\hline TACC $_{\text {it }}$ & \multicolumn{4}{|c|}{ (Laba bersih - arus kas bersih dari operasi) / total aset awal tahun } \\
\hline $\mathrm{LEV}_{\text {it }}$ & \multicolumn{4}{|c|}{ Utang jangka panjang / total aset } \\
\hline $\mathrm{SIZE}_{\text {it }}$ & \multicolumn{4}{|c|}{ Logaritma natural total aset } \\
\hline CAPINT $_{\text {it }}$ & \multicolumn{4}{|c|}{ Net aset tetap / total asset } \\
\hline LOSS $_{\text {it }}$ & \multicolumn{4}{|c|}{$\begin{array}{l}\text { Bernilai } 1 \text { apabila perusahaan mengalami kerugian, dan } 0 \text { jika } \\
\text { sebaliknya }\end{array}$} \\
\hline $\mathrm{AGE}_{\text {it }}$ & \multicolumn{4}{|c|}{$\begin{array}{l}\text { Selisih antara tahun di mana perusahaan memulai operasi dan tahun } \\
\text { laporan keuangan }\end{array}$} \\
\hline $\mathrm{GP}_{\text {it }}$ & \multicolumn{4}{|c|}{ Perubahan pendapatan / pendapatan tahun sebelumnya } \\
\hline
\end{tabular}

Sumber: Penulis

Hasil uji $F$ menunjukkan nilai 0.0000 yang menunjukkan bahwa model regresi yang dihasilkan telah sesuai untuk menjelaskan pengaruh pelaporan keuangan agresif terhadap penghindaran pajak. Ditinjau dari nilai R2, variabel independen mampu menjelaskan $51,5 \%$ dari variasi variabel individu.

Hasil penelitian ini menunjukkan bahwa dengan tingkat keyakinan 99\%, pelaporan keuangan agresif berpengaruh positif signifikan terhadap penghindaran pajak. Dengan kata lain, semakin agresif pelaporan keuangan suatu perusahaan, maka semakin tinggi pula tingkat penghindaran pajaknya. Oleh karena itu, HA yang menyatakan bahwa "pelaporan keuangan agresif berpengaruh terhadap penghindaran pajak perusahaan sektor mineral dan batubara", dapat diterima. Koefisien sebesar 0.04611 pada variabel TACC dapat diartikan bahwa ketika TACC naik satu poin, maka BTD akan meningkat sebesar $4,6 \%$.

Hasil penelitian ini mendukung penelitian sebelumnya yang dilakukan oleh Frank et al. (2006) di Amerika, Kamila dan Martani (2014), serta Ridha dan Martani (2014) di Indonesia dan Amidu et al. (2019) di Ghana yang menemukan bahwa pelaporan keuangan agresif berpengaruh positif secara signifikan terhadap penghindaran pajak.

Penghindaran pajak dalam penelitian ini diwakili oleh book-tax difference (BTD), yaitu selisih antara laba komersial dengan laba fiskal. Sedangkan pelaporan keuangan agresif dalam penelitian ini diwakili oleh nilai total akrual (TACC), yaitu selisih antara laba bersih dengan arus kas bersih dari aktivitas operasi. Koefisien bertanda positif dapat diartikan bahwa semakin tinggi nilai total akrual, maka nilai book-tax difference juga semakin tinggi dan sebaliknya. Artinya, 
semakin tinggi nilai total akrual perusahaan, semakin besar pula selisih antara laba komersial dan laba fiskal.

Hasil penelitian mendukung pendapat Dhaliwal et al. (2004) yang mengatakan bahwa upaya perusahaan untuk memperbesar laba yang dilaporkan dapatHasil penelitian ini mendukung penelitian sebelumnya yang dilakukan oleh Frank et al. (2006) di Amerika, Kamila dan Martani (2014), serta Ridha dan Martani (2014) di Indonesia dan Amidu et al. (2019) di Ghana yang menemukan bahwa pelaporan keuangan agresif berpengaruh positif secara signifikan terhadap penghindaran pajak.

Penghindaran pajak dalam penelitian ini diwakili oleh book-tax difference (BTD), yaitu selisih antara laba komersial dengan laba fiskal. Sedangkan pelaporan keuangan agresif dalam penelitian ini diwakili oleh nilai total akrual (TACC), yaitu selisih antara laba bersih dengan arus kas bersih dari aktivitas operasi. Koefisien bertanda positif dapat diartikan bahwa semakin tinggi nilai total akrual, maka nilai book-tax difference juga semakin tinggi dan sebaliknya. Artinya, semakin tinggi nilai total akrual perusahaan, semakin besar pula selisih antara laba komersial dan laba fiskal.

Hasil penelitian mendukung pendapat Dhaliwal et al. (2004) yang mengatakan bahwa upaya perusahaan untuk memperbesar laba yang dilaporkan dapat mengakibatkan turunnya tarif pajak efektif. Dalam rangka memperbesar laba, salah satu cara yang dapat ditempuh adalah dengan menghemat beban, dan pajak merupakan salah satu komponen beban yang dapat dihemat.

Pelaporan keuangan agresif dapat melibatkan manipulasi pendapatan kena pajak melalui skema penghindaran pajak yang kompleks untuk mempengaruhi besarnya beban pajak yang dilaporkan (Desai \& Dharmapala, 2009). Hal ini dapat dilakukan dengan memanfaatkan perbedaan ketentuan antara standar akuntansi keuangan dan peraturan perpajakan sehingga perusahaan dapat memperbesar laba komersial dan di lain sisi memperkecil laba fiskal (Frank et al., 2006; Kamila \& Martani, 2014).

Berdasarkan uraian di atas, dapat ditafsirkan bahwa pelaporan keuangan agresif dapat melibatkan tax planning. Ketika perusahaan memilih kebijakan yang meningkatkan laba komersial, mereka cenderung lebih agresif dalam pelaporan perpajakannya. Sedangkan ketika perusahaan memilih kebijakan yang menurunkan laba komersial, mereka cenderung kurang agresif dalam hal perpajakannya.

Pengaruh positif pelaporan keuangan agresif terhadap penghindaran pajak mengindikasikan bahwa ketika perusahaan memiliki akrual yang tinggi mereka cenderung melakukan koreksi negatif yang tinggi pula. Hal ini sejalan dengan pendapat Hanlon dan Heitzman (2010) yang mengatakan bahwa perusahaan dapat melakukan manajemen laba yang bertujuan untuk membesar-besarkan laba komersial dengan menyusun transaksi yang dapat memperbesar book-tax difference. Book-tax difference muncul ketika proses rekonsiliasi fiskal dilakukan. Ketika perusahaan melaporkan penghasilannya kepada otoritas perpajakan, laba yang dihitung dengan mengacu pada standar akuntansi harus disesuaikan dengan ketentuan perpajakan untuk menghasilkan laba fiskal. Book-tax difference tersebut dapat dihasilkan dari perbedaan yang bersifat temporer, seperti perbedaan estimasi; perbedaan tetap, seperti beban yang tidak dapat dikurangkan dan pengecualian penghasilan; serta adanya kompensasi kerugian yang dapat dimanfaatkan.

Ditinjau dari peraturan perpajakan, beberapa hal berikut ini dapat memperbesar book-tax difference: koreksi penghasilan dan beban. Mangoting (1999) mengatakan bahwa perusahaan dapat memanfaatkan ketentuan perpajakan yang mengatur jenis pendapatan yang bukan objek pajak dan beban yang dapat dikurangkan, sehingga mereka akan berusaha memaksimalkan pendapatan yang bukan objek pajak dan disisi lain menggeser beban yang tidak dapat dikurangkan (non-deductible expense) menjadi beban yang dapat dikurangkan (deductible expense).

Peraturan perpajakan juga mengenal penghasilan yang bersifat final. Apabila suatu jenis penghasilan dikenai pajak dengan tarif yang bersifat final atau dikecualikan dari objek pajak, maka penghasilan tersebut tidak boleh digabungkan dengan penghasilan lain yang dikenai tarif umum. Di sisi lain, beban-beban terkait penghasilan tersebut tidak boleh dikurangkan. Akibatnya perusahaan memiliki insentif untuk mengatur agar beban-beban yang timbul dapat dikurangkan dan memperkecil beban terkait penghasilan yang bersifat final atau dikecualikan dari objek pajak tersebut.

Penyusutan. Terdapat beberapa ketentuan SAK dan peraturan perpajakan yang dapat memperbesar book-tax difference. Pertama, perbedaan ketentuan depresiasi dan amortisasi dapat menyebabkan nilai beban depresiasi/amortisasi fiskal di atas depresiasi/amortisasi komersial. Kedua, revaluasi aset tetap untuk tujuan perpajakan dapat menyebabkan beban depresiasi meningkat sehingga menurunkan laba fiskal. Ketiga, pengakuan properti investasi menurut SAK diukur dengan nilai wajar sedangkan menurut perpajakan diakui sebagai aktiva tetap dan disusutkan.

Kompensasi kerugian. Dilihat dari statistik perusahaan pertambangan mineral dan batubara sebagaimana disajikan pada subbab deskriptif statistik, sebagian perusahaan mengalami kerugian operasi. Aturan perpajakan memungkinkan rugi tersebut dapat dikompensasikan dengan laba di periode selanjutnya. Perusahaan akan memiliki simpanan rugi fiskal yang dapat digunakan ketika laba. Akibatnya ketika perusahaan mendapat laba komersial, kompensasi kerugian periode sebelumnya akan mengurangi laba fiskal pada periode kini. Hal ini menyebabkan laba fiskal akan lebih kecil daripada laba komersial. Selain itu, pemanfaatan kompensasi kerugian dapat terjadi ketika perusahaan melakukan merger dengan perusahaan yang memiliki kompensasi kerugian. Dalam melakukan 
merger dengan perusahaan yang memiliki kompensasi kerugian, perusahaan yang mengakuisisi dapat mengakui cadangan rugi fiskal perusahaan yang diakuisisi.

Transaksi dengan grup usaha. Ada kemungkinan bagi perusahaan-perusahaan induk atau anak, ketika memiliki laba konsolidasian cukup tinggi, mereka dengan sengaja memilih untuk menciptakan kerugian pada perusahaan tertentu yang menjadi anggota grup dengan tujuan menghindari pembayaran pajak di masa kini atau memperkecil laba fiskal di masa mendatang. Dilihat dari karakteristiknya, banyak perusahaan batubara merupakan perusahaan kelompok yang memiliki banyak afiliasi dengan jenis usaha yang kadang terdiversifikasi. Karakteristik ini dapat memberi peluang bagi mereka untuk menggeser laba melalui berbagai skema, salah satunya transfer pricing. Transfer pricing akan menurunkan beban pajak konsolidasi, apabila terdapat pergeseran laba dari perusahaan yang mengalami keuntungan ke perusahaan yang mengalami kerugian. Setiawan (2014) menjelaskan bahwa abuse of transfer pricing akan berdampak signifikan terhadap penerimaan pajak apabila dilakukan oleh perusahaan multinasional yang mempunyai anak-anak perusahaan di berbagai negara (international transfer pricing). Sedangkan domestic transfer pricing tidak berpengaruh secara signifikan terhadap potensi penerimaan pajak karena pengurangan laba/penghasilan di satu perusahaan akan mengakibatkan penambahan laba/penghasilan di perusahaan lainnya sehingga hasilnya akan sama ke penerimaan pajak, kecuali digunakan untuk mengalihkan laba dari suatu perusahaan ke perusahaan lain yang masih berhak menikmati kompensasi kerugian.

Kondisi-kondisi diatas diakibatkan oleh adanya perbedaan aturan standar akuntansi dan aturan perpajakan. Hal ini sejalan dengan pendapat Frank et al. (2006) yang menyatakan bahwa perbedaan ketentuan antara standar akuntansi keuangan dan peraturan perpajakan dapat dimanfaatkan oleh perusahaan untuk bertindak agresif dalam pembukuan komersil dan fiskal pada saat yang sama, dan akibatnya, perusahaanperusahaan ini secara bersamaan melaporkan laba komersial yang lebih tinggi dan laba fiskal yang lebih rendah.

Hubungan negatif antara pelaporan keuangan agresif dan penghindaran pajak juga dapat ditinjau dari motivasinya. Peningkatan nilai total akrual menandakan bahwa peningkatan laba komersial tidak selaras dengan peningkatan kas yang diperoleh. Peningkatan laba di satu sisi menandakan kinerja yang baik namun di sisi lain menandakan beban pajak yang harus dibayar meningkat. Akibatnya ada insentif bagi perusahaan untuk menghemat uang dengan memperkecil pembayaran pajak. Hal ini sejalan dengan pendapat Chen et al. (2010) mengatakan bahwa manfaat paling nyata dari penghindaran pajak adalah penghematan uang yang dapat dinikmati baik oleh pemegang saham maupun manajer.

\section{Pengaruh Leverage terhadap Penghindaran Pajak}

Variabel leverage (LEV) memiliki nilai koefisien sebesar -0.01693 yang mengandung arti bahwa apabila leverage meningkat 1 poin, Penghindaran Pajak akan turun sebesar $1.7 \%$. Walaupun koefisien LEV menunjukkan tanda negatif, namun pengaruh LEV dalam penelitian ini tidak signifikan secara statistik terhadap penghindaran pajak. Hal ini terlihat dari nilai $\mathrm{P}>|\mathrm{t}|$ sebesar 0.204 atau signifikan pada tingkat $25 \%$ sehingga dapat disimpulkan bahwa leverage tidak berpengaruh terhadap penghindaran pajak. Hasil ini mendukung beberapa penelitian sebelumnya seperti Taylor dan Richardson (2012) serta Kamila dan Martani (2014) yang menunjukkan hasil yang sama.

Peraturan perpajakan Indonesia memberi perlakuan tersendiri terhadap biaya bunga. Direktorat Jenderal Pajak membatasi pembebanan biaya bunga utang yang dapat menjadi pengurang penghasilan fiskal. Hal ini tercantum dalam Surat Edaran Direktur Jenderal Pajak Nomor 46 Tahun 1995 yang menyatakan bahwa apabila jumlah rata-rata pinjaman sama besarnya dengan atau lebih kecil dari jumlah rata-rata dana yang ditempatkan sebagai deposito berjangka atau tabungan lainnya, maka bunga yang dibayar atau terutang atas pinjaman tersebut seluruhnya tidak dapat dibebankan sebagai biaya. Sedangkan apabila jumlah rata-rata pinjaman lebih besar dari jumlah rata-rata dana yang ditempatkan dalam bentuk deposito atau tabungan lainnya, maka bunga atas pinjaman yang boleh dibebankan sebagai biaya adalah bunga yang dibayar atau terutang atas rata-rata pinjaman yang melebihi jumlah rata-rata dana yang ditempatkan sebagai deposito berjangka atau tabungan lainnya. Adanya peraturan tersebut mungkin menyebabkan leverage tidak berpengaruh terhadap penghindaran pajak.

\section{Pengaruh Ukuran Perusahaan terhadap Penghindaran Pajak}

Variabel ukuran perusahaan (SIZE) memiliki nilai koefisien 0.00017 yang mengandung arti bahwa apabila SIZE meningkat 1 poin, penghindaran pajak akan meningkat sebesar $0.017 \%$. Meskipun demikian, pengaruh SIZE dalam penelitian ini tidak signifikan secara statistik terhadap penghindaran pajak, dilihat dari nilai $P>|t|$ sebesar 0.967. Oleh karena itu, dapat disimpulkan bahwa secara statistik SIZE tidak berpengaruh terhadap penghindaran pajak. Hasil ini mendukung beberapa hasil penelitian sebelumnya seperti Gupta dan Newberry (1997), Ridha dan Martani (2014), serta Amidu et al. (2019).

Gupta dan Newberry (1997) melakukan penelitian terhadap perusahaan yang memiliki data keuangan selama 3 tahun dan 8 tahun dan menemukan bahwa efek ukuran perusahaan terhadap penghindaran 
pajak dipengaruhi oleh lamanya perusahaan beroperasi. Dalam hal ini pengaruh SIZE tidak signifikan terhadap penghindaran pajak ketika penelitian dilakukan untuk perusahaan yang memiliki sejarah operasi lebih panjang.

Menurut teori biaya politik, perusahaan yang lebih besar dan lebih makmur menanggung biaya politik yang lebih besar karena mereka menjadi sasaran kebijakan pemerintah, termasuk kebijakan transfer pendapatan dalam bentuk pajak (Watts \& Zimmerman, 1978). Perusahaan besar dituntut untuk lebih patuh dalam memenuhi kewajiban perpajakannya sehingga walaupun perusahaan dapat merencanakan dan melaksanakan strategi investasi dengan lebih efisien dengan memanfaatkan aset yang menguntungkan secara perpajakan, namun perhatian regulator membuat mereka sulit melakukan penghindaran pajak melalui pemanfaatan aset.

\section{Pengaruh Capital Intensive terhadap Penghindaran Pajak}

Koefisien variabel capital intensive (CAPINT) bertanda "positif" atau searah yaitu sebesar 0.00274 mengandung arti bahwa jika variabel capital intensive naik satu poin, maka nilai BTD akan naik sebesar $0.27 \%$. Meskipun demikian, pengaruh capital intensive dalam penelitian ini tidak signifikan secara statistik terhadap penghindaran pajak, dilihat dari nilai $\mathrm{P}>|\mathrm{t}|$ sebesar 0.388 atau signifikan pada tingkat $40 \%$. Oleh karena itu, dapat disimpulkan bahwa secara statistik capital intensive tidak berpengaruh terhadap penghindaran pajak.

Hasil ini sejalan dengan hasil penelitian Taylor dan Richardson (2012) serta Liu dan Cao (2007) yang menunjukkan bahwa kepemilikan aset tetap tidak memberikan pengaruh dalam pengurangan pembayaran pajak. Kepemilikan aset tetap oleh suatu perusahaan bukan semata-mata untuk menghindari pajak melainkan untuk menjalankan operasi perusahaan.

Selain itu, capital intensive berkaitan dengan besarnya beban depresiasi dan amortisasi dimana beban tersebut dihitung menurut standar akuntansi dan peraturan perpajakan yang mungkin memiliki kesamaan penghitungan. Ketika perusahaan di sektor pertambangan mineral dan batubara menggunakan metode estimasi yang sama baik untuk pelaporan komersial maupun pelaporan fiskal, maka adanya beban depresiasi dan amortisasi tidak akan memperbesar book-tax difference. Hal ini mungkin menyebabkan capital intensive tidak berpengaruh terhadap penghindaran pajak.

\section{Pengaruh Rugi terhadap Penghindaran Pajak}

Koefisien regresi pada variabel rugi sebelum pajak penghasilan (LOSS) bertanda negatif atau tidak searah yaitu sebesar -0.01343 . Variabel LOSS merupakan dummy, sehingga hal ini berarti bahwa apabila perusahaan menderita kerugian sebelum beban pajak penghasilan, maka nilai BTD akan turun sebesar $1,34 \%$. Pengaruh LOSS dalam penelitian ini signifikan secara statistik pada tingkat $1 \%$ terhadap BTD, dilihat dari nilai $\mathrm{P}>|\mathrm{t}|$ sebesar 0.000 dan nilai confidence interval 99\%. Hasil ini mendukung hasil penelitian Tang dan Firth (2011).

Tujuan perusahaan melakukan penghindaran pajak adalah untuk memperkecil pembayaran pajaknya. Perusahaan yang rugi tidak akan dikenai pajak penghasilan sehingga motivasi untuk melakukan penghindaran pajak juga hilang. Perusahaan yang mengalami kerugian cenderung tidak akan melakukan penghindaran pajak karena mereka tidak akan mendapat keuntungan dari tindakan tersebut. Di sisi lain, penghindaran pajak merupakan praktik yang berisiko menarik perhatian regulator (Desai \& Dharmapala, 2006; Frank et al., 2006)

Selain itu, hubungan negatif juga muncul akibat adanya perlakuan asimetris terhadap kerugian antara pembukuan komersial dan fiskal. Tang dan Firth (2011) mengatakan bahwa pengaruh LOSS negatif terhadap BTD karena BTD akan understated ketika muncul kerugian. Perusahaan yang mengalami kerugian akan melaporkan rugi komersial namun penghasilan kena pajak dilaporkan nihil karena kerugian fiskal akan dikompensasikan ke masa selanjutnya.

\section{Pengaruh Usia Perusahaan terhadap Penghindaran Pajak}

Koefisien variabel usia perusahaan (AGE) bertanda positif sebesar 0.00039 mengandung arti bahwa jika variabel AGE naik satu poin, maka nilai BTD akan naik sebesar 0,04\%. Meskipun demikian, pengaruh AGE dalam penelitian ini tidak signifikan secara statistik terhadap penghindaran pajak, dilihat dari nilai $\mathrm{P}>|\mathrm{t}|$ sebesar 0.187 atau signifikan pada tingkat $20 \%$. Oleh karena itu, dapat disimpulkan bahwa secara statistik AGE tidak berpengaruh terhadap penghindaran pajak. Hasil ini sejalan dengan hasil penelitian Richardson, Taylor, dan Lanis (2015) yang menemukan bahwa usia perusahaan tidak berpengaruh terhadap penghindaran pajak.

Ada beberapa kemungkinan mengapa kesimpulan ini dihasilkan. Pertama, menurut statistik deskriptif, terhitung hingga tahun 2018 sampel yang digunakan adalah perusahaan yang telah beroperasi selama 11 hingga 50 tahun. Artinya, perusahaan sampel cukup lama berdiri sehingga secara umum mereka memiliki pengalaman dan keahlian yang setara terkait perencanaan pajak.

Kedua, banyaknya konsultan perpajakan membuat akses perusahaan terhadap informasi perpajakan semakin mudah. Selain itu, konsultan perpajakan dapat membantu mereka dalam melakukan tax planning. Baik perusahaan yang sudah lama berdiri atau yang lebih baru berdiri dapat menggunakan jasa 
konsultan perpajakan tersebut sehingga faktor pengalaman menjadi tidak relevan lagi.

\section{Pengaruh Growth Potential terhadap Penghindaran Pajak}

Berkaitan dengan variabel kontrol, GP berpengaruh positif signifikan secara statistik pada tingkat $5 \%$ terhadap penghindaran pajak dengan nilai koefisien sebesar 0.00523 . Hal ini dapat dilihat dari nilai $\mathrm{P}>|\mathrm{t}|$ sebesar 0.03 untuk one tailed test. Hasil ini sejalan dengan penelitian Amidu et al. (2019) yang menunjukkan bahwa semakin tinggi pertumbuhan pendapatan, semakin tinggi pula tingkat penghindaran pajak perusahaan.

Hasil ini didukung oleh teori keagenan yang mengatakan bahwa masing-masing individu adalah utility maximizer. Ketika perusahaan memperoleh pendapatan yang tinggi, beban pajak yang dibayarnya akan semakin besar. Pajak yang dibayar akan mengurangi keuntungan sehingga perusahaan akan berusaha menghemat pembayaran pajaknya melalui skema penghindaran pajak.

\section{Kesimpulan}

Hasil penelitian menunjukkan bahwa pelaporan keuangan agresif berpengaruh positif signifikan terhadap penghindaran pajak. Arah positif menandakan bahwa terjadi hubungan searah antara pelaporan keuangan agresif dengan penghindaran pajak sehingga semakin agresif pelaporan keuangan suatu perusahaan, maka semakin tinggi pula tingkat penghindaran pajaknya. Hal ini mengindikasikan bahwa perusahaan yang bergerak di sektor industri pertambangan mineral dan batubara yang terdaftar di BEI cenderung melakukan penghematan pajak ketika mereka memperbesar laba komersial.

Hasil penelitian ini menunjukkan pengaruh positif agresivitas pelaporan keuangan terhadap penghindaran pajak. Koefisien menunjukkan angka 0,046 - 0,066\% yang mengandung arti bahwa apabila nilai akrual naik satu basis poin, maka penghindaran pajak akan meningkat sebesar 4,6\%-6,6\%. Hasil penelitian ini mendukung beberapa penilitian sebelumnya, seperti Frank et al. (2009), Kamila dan Martani (2014), serta Amidu et al. (2019) yang menemukan bahwa pelaporan keuangan agresif berpengaruh secara positif terhadap penghindaran pajak.

Lebih lanjut, penelitian ini juga mengungkap bahwa growth potential berpengaruh positif terhadap penghindaran pajak. Rugi sebelum operasi berpengaruh negatif terhadap penghindaran pajak. Sedangkan leverage, size, capital intensiive, dan age tidak berpengaruh terhadap penghindaran pajak.

Hasil penelitian ini menunjukkan pengaruh positif yang signifikan dari pelaporan keuangan agresif terhadap penghindaran pajak perusahaan, dimana pelaporan keuangan agresif diukur dengan nilai total akrual. Direktorat Jenderal Pajak (DJP) dalam hal ini dapat mempertimbangkan untuk memasukkan variabel nilai total akrual sebagai komponen untuk menilai risiko ketidakpatuhan wajib pajak dalam menjalankan fungsi pengawasan atau pemeriksaan. DJP dapat melakukan benchmarking terhadap nilai total dan akrual perindustri kemudian menyusun indikator ketidakpatuhan untuk melengkapi kriteria prioritas Wajib Pajak yang diperiksa sesuai SE-15/PJ/2018 tentang kebijakan pemeriksaan. Selain itu, growth potential juga menunjukkan pengaruh positif yang signifikan terhadap penghindaran pajak. Hasil ini dapat dijadikan oleh DJP sebagai indikator untuk menilai risiko kepatuhan wajib pajak.

\section{DAFTAR PUSTAKA (REFERENCES)}

Amidu, M., Coffie, W., \& Acquah, P. (2019). Transfer pricing, earnings management and tax avoidance of firms in Ghana. Journal of Financial Crime, 26(1), 235-259.

Ardyaksa, T. K., \& Kiswanto, K. (2014). Pengaruh Keadilan, Tarif Pajak, Ketepatan Pengalokasian, Kecurangan, Teknologi dan Informasi Perpajakan Terhadap Tax Evasion. Accounting Analysis Journal, 3(4).

Bergstresser, D., \& Philippon, T. (2006). CEO incentives and earnings management. Journal of financial economics, 80(3), 511-529.

Besley, T., \& Persson, T. (2014). Why do developing countries tax so little? Journal of Economic Perspectives, 28(4), 99-120.

Blaufus, K., Hundsdoerfer, J., Jacob, M., \& Sünwoldt, M. (2016). Does legality matter? The case of tax avoidance and evasion. Journal of Economic Behavior \& Organization, 127, 182-206.

Brown, K. B. (2012). Comparative Regulation of Corporate Tax Avoidance: An Overview. In A Comparative Look at Regulation of Corporate Tax Avoidance (pp. 1-21): Springer.

Chen, S., Chen, X., Cheng, Q., \& Shevlin, T. (2010). Are family firms more tax aggressive than non-family firms? Journal of Financial Economics, 95(1), 41-61.

Chen, T. (2010). Analysis on accrual-based models in detecting earnings management. Lingnan Journal of Banking, Finance and Economics, 2(1), 5.

Cooper, D., \& Schindler, P. (2014). Business Research Methods. (C) The McGraw- Hill Companies.

Dechow, P., Ge, W., \& Schrand, C. (2010). Understanding earnings quality: A review of the proxies, their determinants and their consequences. Journal of accounting and economics, 50(2-3), 344-401.

Desai, M. A., \& Dharmapala, D. (2006). Corporate tax avoidance and high-powered incentives. Journal of Financial Economics, 79(1), 145-179. 
Desai, M. A., \& Dharmapala, D. (2009). Earnings management, corporate tax shelters, and book-tax alignment. National Tax Journal, 169-186.

Dhaliwal, D. S., Gleason, C. A., \& Mills, L. F. (2004). Lastchance earnings management: Using the tax expense to meet analysts' forecasts. Contemporary Accounting Research, 21(2), 431459.

Direktorat Jenderal Pajak. https://www.pajak.go.id/id/sistem-perpajakan (diakses pada 14 November 2019)

Dyreng, S. D., Hanlon, M., \& Maydew, E. L. (2010). The effects of executives on corporate tax avoidance. The Accounting Review, 85(4), 1163-1189.

Ewert, R., \& Wagenhofer, A. (2005). Economic effects of tightening accounting standards to restrict earnings management. The Accounting Review, 80(4), 1101-1124.

Fischer, M., \& Rosenzweig, K. (1995). Attitudes of students and accounting practitioners concerning the ethical acceptability of earnings management. Journal of business ethics, 14(6), 433-444.

Frank, M., Lynch, L., \& Rego, S. (2006). Does aggressive financial reporting accompany aggressive tax reporting (and vice versa). University of Virginia. Mimeo.

Frank, M. M., Lynch, L. J., \& Rego, S. O. (2009). Tax reporting aggressiveness and its relation to aggressive financial reporting. The Accounting Review, 84(2), 467-496. 102

Gill, A., Biger, N., Mand, H. S., \& Mathur, N. (2013). Earnings management, firm performance, and the value of Indian manufacturing firms. International Research Journal of Finance and Economics, 116, 13-26.

Global Witness. (2019). Pengalihan Uang Batubara Indonesia, Bagian 3: Jaringan Luar Negeri Milik Adaro.

Godfrey, J., Hodgson, A., Tarca, A., Hamilton, J., \& Holmes, S. (2010). Accounting theory.

Gujarati, D., \& Porter, C. (2009). Dawn (2009). Basic Econometrics. Fifth Edition. Mc. Grow-Hill, New York.

Gupta, S., \& Newberry, K. (1997). Determinants of the variability in corporate effective tax rates: Evidence from longitudinal data. Journal of accounting and public policy, 16(1), 1-34.

Hackenbrack, K., \& Nelson, M. W. (1996). Auditors' incentives and their application of financial accounting standards. Accounting Review, 43-59.

Hanlon, M., \& Heitzman, S. (2010). A review of tax research. Journal of accounting and Economics, 50(2-3), 127-178.

Hanna, H., \& Haryanto, M. (2016). Agresivitas Pelaporan Keuangan, Agresivitas Pajak, Tata Kelola Perusahaan dan Kepemilikan Keluarga. Universitas Tarumanagara Journal of Accounting, 20(3).
Healy, P. M., \& Wahlen, J. M. (1999). A review of the earnings management literature and its implications for standard setting. Accounting horizons, 13(4), 365-383.

Indonesia Corruption

Watch. https://antikorupsi.org/id/kajian/tata-kelolabatubara-belum-maksimal-kerugian-negaradiindikasikan-capai-1336-triliun-rupiah (diakses pada 23 Oktober 2019)

Johannesen, N., Tørsløv, T., \& Wier, L. (2016). Are less developed countries more exposed to multinational tax avoidance? Method and evidence from micro-data (No. 2016/10). WIDER Working Paper.

Jones, J. J. (1991). Earnings management during import relief investigations. Journal of accounting research, 29(2), 193-228.

Kementerian Komunikasi dan Informatika. https://www.kominfo.go.id/content/ detail/8651/aksi-sri-mulyani-berburu-pajakgoogle-berlanjut-di-tahun-baru/0/ sorotan_media (diakses pada 18 November 2019) 103

Kementerian Komunikasi dan Informatika. https://kominfo.go.id/content/detail/9520/ realisasi-tax-amnesty-deklarasi-rp48134-triliundan-repatriasi-rp146-triliun/0/ berita (diakses pada 18 November 2019)

Kim, W. J., \& Jang, G. B. (2018). RELATIONSHIP BETWEEN TAX AVOIDANCE AND KEY FINANCIAL INDICATORS IN KOREA'S CONSTRUCTION WASTE DISPOSAL INDUSTRY. Academy of Accounting \& Financial Studies Journal, 22(3).

Kontan. https://industri.kontan.co.id/news/soaltransfer-pricing-batubara-apbi nampaknyapengusaha-harus-berpikir-berkali-kali (diakses pada 3 November 2019)

Kristanto, S. B. (2015). Dampak Praktek Manajemen Laba terhadap Manajemen Pajak Perusahaan. Disertasi, Universitas Kristen Krida Wacana.

Kurniawati, L. (2018). Tax Amnesty upaya Memperkuat Penerimaan Negara Sektor Pajak. Substansi, 1(2), 238-264.

Lennox, C., Lisowsky, P., \& Pittman, J. (2013). Tax aggressiveness and accounting fraud. Journal of Accounting Research, 51(4), 739-778.

Liputan https://www.liputan6.com/bisnis/read/3158339/i cw-ada-indikasi-negara-rugi-rp-133-t-dari-eksporbatu-bara (diakses pada 18 November 2019)

Liu, X., \& Cao, S. (2007). Determinants of corporate effective tax rates: evidence from listed companies in China. Chinese economy, 40(6), 49-67.

Mangoting, Y. (2004). Tax Planning: Sebuah Pengantar Sebagai Alternatif Meminimalkan Pajak. Jurnal Akuntansi dan Keuangan, 1(1), 43-53.

Maulana, T. I., \& Muchtar, P.P.S.A., (2018). Modul Metode Penelitian Akuntansi. Jakarta: Politeknik Keuangan Negara STAN. 
Martani, D., \& Kamila, P. (2014). Analisis Hubungan Agresivitas Pelaporan Keuangan dan Agresivitas Pajak. Simposium Nasional Akuntansi XVII.

McGuire, S. T., Omer, T. C., \& Wang, D. (2012). Tax avoidance: Does tax-specific industry expertise make a difference? The Accounting Review, 87(3), 975-1003.

Moore, J. A. (2012). Empirical evidence on the impact of external monitoring on book-tax differences. Advances in Accounting, 28(2), 254-269. 104

Phillips, F. (1999). Auditor attention to and judgments of aggressive financial reporting. Journal of accounting research, 37(1), 167-189.

Republika.

https://nasional.republika.co.id/berita/nwc9wn38 4/indonesia-darurat-aliran-uang-ilegal (diakses pada 7 November 2019)

Richardson, G., Taylor, G., \& Lanis, R. (2015). The impact of financial distress on corporate tax avoidance spanning the global financial crisis: Evidence from Australia. Economic Modelling, 44, 44-53.

Richardson, S. A., Tuna, A., \& Wu, M. (2002). Predicting earnings management: The case of earnings restatements. Available at SSRN 338681.

Ridha, M., \& Martani, D. (2014). Analisis Terhadap Agresivitas Pajak, Agresivitas Pelaporan Keuangan, Kepemilikan Keluarga, dan Tata Kelola Perusahaan di Indonesia. Simposium Nasional Akuntansi XVII, Mataram.

Roychowdhury, S. (2006). Earnings management through real activities manipulation. Journal of accounting and economics, 42(3), 335-370.

Sarker, T. K. (2003). Improving Tax Compliance in Developing Countries via Self-Assessment Systems-What Could Bangladesh Learn from Japan. Asia-Pacific Tax Bulletin, 9(6), 3-34.

Scott, W. R. (2015). Financial Accounting Theory Seventh Edition. United States: Canada Cataloguing.

Sekaran, U., \& Bougie, R. (2016). Research methods for business: A skill building approach: John Wiley \& Sons.

Setiawan, A. (2017). Peranan KPP Pratama Dalam Meningkatkan Jumlah Wajib Pajak Di Kabupaten Kebumen. Skripsi Program Studi S1 Ilmu Hukum Fakultas Hukum Universitas Muhammadiyah Yogyakarta.

Setiawan, H. (2014). Transfer Pricing Dan Resikonya terhadap Penerimaan Negara. https://www.kemenkeu.go.id/sites/default/files/ 2014kajian_pprf_transfer\%20pricing\%20dan\%20ri sikonya\%20terhadap\%20penerimaan\%20negara.p df (diakses pada 22 Oktober 2019)

Sindonews.

https://nasional.sindonews.com/read/1450627/1 8/djp-pimpin-otoritas-pajak-di-asia-pasifik-bahasisu-pajak-strategis-1571592330 (diakses pada 4 November 2019)
Sugiyono. 2018. Metode Penelitian Kuantitatif, Kualitatif dan R \& D. Bandung: Alfabeta. 105

Susilatri, S., \& Sartika, M. (2015). Analisis Perbedaan Penghindaran Pajak (Tax Avoidance) Pada Perusahaan Yang Dikenai Pajak Penghasilan Final Dan Perusahaan Yang Dikenai Pajak Penghasilan Tidak Final. Jurnal Online Mahasiswa Fakultas Ekonomi Universitas Riau, 2(1).

Tang, T., \& Firth, M. (2011). Can book-tax differences capture earnings management and tax management? Empirical evidence from China. The International Journal of Accounting, 46(2), 175204.

Taylor, G., \& Richardson, G. (2012). International corporate tax avoidance practices: evidence from Australian firms. The International Journal of Accounting, 47(4), 469-496.

Watts, R. L., \& Zimmerman, J. L. (1978). Towards a positive theory of the determination of accounting standards. Accounting review, 112-134.

Widhiarso, W. (2011) Analisis Data Penelitian dengan Variabel Kontrol. http://widhiarso.staff.ugm.ac.id/files/Analisis\%20 Data\%20dengan\%20Menggunakan\%20Variabel\% 20Kontrol.pdf (diakses pada 23 Oktober 2019) 